\title{
Effects of Copper Addition on the Passivity and Corrosion Behavior of 27Cr-7Ni Hyper Duplex Stainless Steels in Sulfuric Acid Solution
}

\author{
Soon-Hyeok Jeon*, Hye-Jin Kim, Kyeong-Ho Kong and Yong-Soo Park \\ Department of Material Science and Engineering, Yonsei University, \\ 134 Shinchon-dong, Seodaemun-gu, Seoul 120-749, Republic of Korea
}

The effect of the $\mathrm{Cu}$ addition on the passivation behavior of hyper duplex stainless steels in both the active and passive states was investigated using the electrochemical tests, a scanning electron microscope-energy dispersive spectroscope, a scanning Auger multi-probe analysis and an X-ray photoelectron spectroscopy analysis in sulfuric acid solution. In the active region of $-0.2 \mathrm{~V}_{\mathrm{SCE}}$, the $\mathrm{Cu}$ addition to the base alloy has a positive effect on the general corrosion resistance due to the novel $\mathrm{Cu}$ enriched on the surface. In the passive region of $0.6 \mathrm{~V}_{\mathrm{SCE}}$, the $\mathrm{Cu}$ addition to the base alloy degraded the stability of passive film due to an increase of the formation of $\mathrm{Cr}$ enriched inclusion such as (Cr, $\mathrm{Mn}$, $\mathrm{Al})$ oxides and $(\mathrm{Cr}, \mathrm{Mn}, \mathrm{Al}, \mathrm{Fe})$ oxides acting as the defect in the passive film, resulting in deteriorating general corrosion resistance. [doi:10.2320/matertrans.M2014233]

(Received June 25, 2014; Accepted October 2, 2014; Published November 8, 2014)

Keywords: copper, duplex stainless steel, polarization, acid corrosion, passivity

\section{Introduction}

Duplex stainless steels with nearly equal fractions of ferrite $(\alpha)$ and austenite $(\gamma)$ phases are being increasingly used for various applications such as fuel gas desulphurization facilities in fossil power plants, desalination facilities, offshore petroleum facilities, and chemical plants due to their high resistance to stress corrosion cracking and pitting corrosion, good weldability, excellent mechanical properties and relatively low cost due to the addition of low $\mathrm{Ni}$, as compared with austenite stainless steels. ${ }^{1-3)}$

Among the minor alloying elements, $\mathrm{Cu}$ is well known alloying element which is used to improve the general corrosion resistance of stainless steel in sulfuric acid solution. ${ }^{4-6)}$ It has been reported in previous studies that the mechanism of the beneficial effect of the $\mathrm{Cu}$ addition on the stainless steels is based on the suppression of the anodic dissolution by the noble metallic $\mathrm{Cu}$ enriched on the surface of stainless steels in the sulfuric acid solution. ${ }^{7-10)}$

Many researchers have been reported the positive effects of $\mathrm{Cu}$ addition on the passivation behavior of stainless steels. Wilde and Greene ${ }^{11)}$ noted that $\mathrm{Cu}$ has a positive effect on the passivation in the acidic solution due to its low hydrogen over potential. Itzhak and Peled ${ }^{12)}$ presented that the $\mathrm{Cu}$ additions enhance the passivation process of the austenitic stainless steel due to a cathodic depolarization effect of hydrogen evolution and oxygen.

On the other hand, $\mathrm{Cu}$ showed detrimental effects on the stability of passive film on the stainless steels. Seo et al. ${ }^{13)}$ showed that the metallic surface layer of $\mathrm{Cu}$ dissolves as cupric ions in the passive potential region which results in a detrimental effect on the stability of the passive film of ferritic stainless steel. Lizlovs ${ }^{14)}$ found that copper reduces the passive film stability of stainless steels containing $1 \%$ Mo, but their the stability was improved by the addition of $\mathrm{Cu}$ when the steels contained 3\% Mo. Postrach et al. ${ }^{15)}$ claimed that the films of alloys containing $\mathrm{Cu}$, according to the accelerated open circuit breakdown of $\mathrm{Cu}$ bearing

*Corresponding author, E-mail: junsoon@yonsei.ac.kr samples, are less stable than expected, which is related to a faster removal of the oxide film. Oguzie et al. ${ }^{16)}$ reported that $\mathrm{Cu}$ has negative effects on the stability of the passive film of austenitic, ferritic and martensitic stainless steels in the sulfuric acid solution due to the presence of $\mathrm{Cu}$ in the passive film as cupric ions increased the donor $\left(N_{\mathrm{D}}\right)$ and acceptor $\left(N_{\mathrm{A}}\right)$ densities affecting the film stability. These inconsistent results on the passivity of stainless steels revealed a very complex role played by $\mathrm{Cu}$.

The addition of $\mathrm{Cu}$ on the various stainless steels shows different behavior in the active and passive region. Therefore, it is essential to confirm the effects of $\mathrm{Cu}$ addition on the passivation behavior in the active and passive region separately. Moreover, few studies have been focused on the effect of $\mathrm{Cu}$ addition on the passivation behavior of hyper duplex stainless steels.

In this work, the effects of the $\mathrm{Cu}$ addition on the general corrosion resistance and passivation behavior in both the active and passive state of hyper duplex stainless steels in the sulfuric acid solution were investigated using a potentiodynamic polarization test, a potentiostatic polarization test, a scanning electron microscope-energy dispersive spectroscope (SEM-EDS), a scanning Auger multi-probe (SAM) analysis and an X-ray photoelectron spectroscopy (XPS) analysis.

\section{Experimental Procedures}

Ingots weighing $50 \mathrm{~kg}$ with dimensions 150 by 150 by $300 \mathrm{~mm}$ (width by length by height) were manufactured using a high frequency vacuum induction furnace. After these ingots were hot rolled in the range of 1333 to $1523 \mathrm{~K}$, plates of $6 \mathrm{~mm}$ thickness were manufactured. The specimens were cut into dimensions of 15 by 15 by $6 \mathrm{~mm}$ (width by length by thickness) and solution heat-treated in air for $5 \mathrm{~min}$ per $1 \mathrm{~mm}$ thickness at $1090^{\circ} \mathrm{C}$ and then quenched in water. The chemical compositions of the alloys are presented in Table 1.

The effects of $\mathrm{Cu}$ addition on the general corrosion resistance of hyper duplex stainless steels were investigated using a potentiodynamic anodic polarization technique in sulfuric acid solution. The corrosion potential $\left(E_{\text {corr }}\right)$, the 

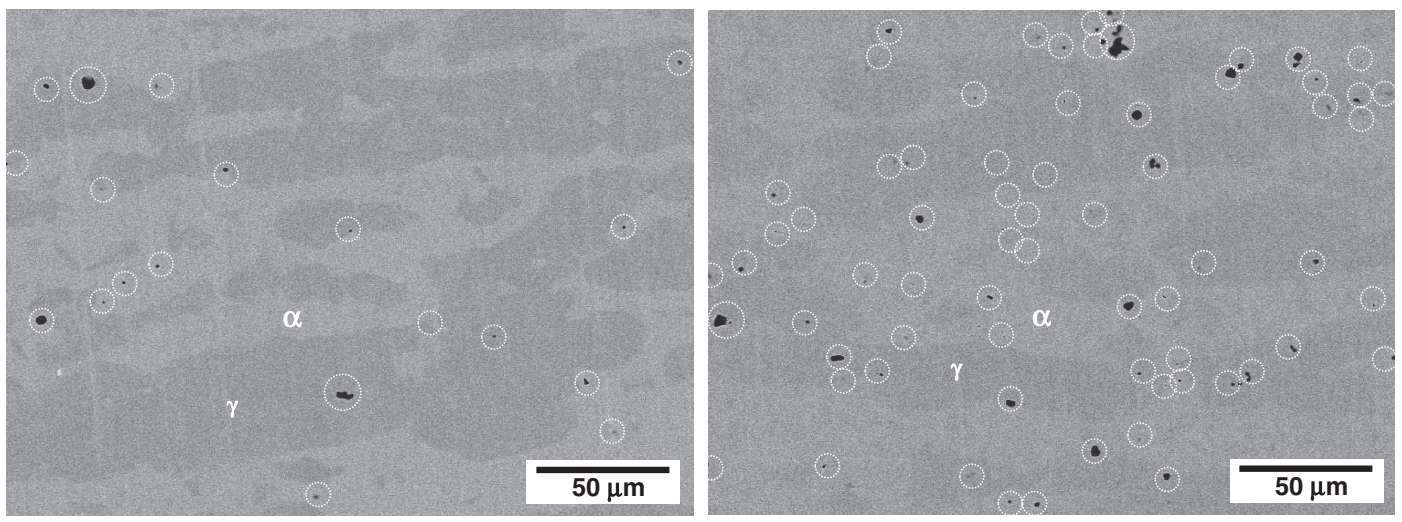

Fig. 1 SEM-BSE images of the microstructure in the alloys: (a) Base alloy and (b) $1.5 \mathrm{Cu}$ alloy.

Table 1 Chemical composition of the experimental alloys (mass\%).

\begin{tabular}{ccccccccccc}
\hline Alloy & $\mathrm{C}$ & $\mathrm{Cr}$ & $\mathrm{Ni}$ & $\mathrm{Mo}$ & $\mathrm{W}$ & $\mathrm{Si}$ & $\mathrm{Mn}$ & $\mathrm{Cu}$ & $\mathrm{N}$ & $\mathrm{Fe}$ \\
\hline Base & 0.020 & 27.01 & 7.00 & 2.52 & 3.28 & 0.35 & 0.88 & - & 0.35 & Bal. \\
\hline $1.5 \mathrm{Cu}$ & 0.017 & 26.91 & 6.59 & 2.50 & 3.30 & 0.33 & 0.94 & 1.45 & 0.38 & Bal. \\
\hline
\end{tabular}

passivation current density $\left(I_{\mathrm{p}}\right)$ and the corrosion current density $\left(I_{\text {corr }}\right)$ were obtained from the potentiodynamic polarization curves. The corrosion current density $\left(I_{\text {corr }}\right)$ was commonly obtained by the extrapolation of the cathodic and anodic curve between 50 and $100 \mathrm{mV}$ away from the corrosion potential. The potentiodynamic anodic polarization test was conducted in a deaerated $2 \mathrm{M} \mathrm{H}_{2} \mathrm{SO}_{4}$ solution at $333 \mathrm{~K}$ according to the ASTM G 5. ${ }^{17)}$ Test specimens were joined with $\mathrm{Cu}$ wire through soldering (95 mass\% Sn5 mass $\% \mathrm{Sb}$ ), and then mounted with an epoxy resin. One side of the sample was ground to 600 grit using $\mathrm{SiC}$ abrasion paper. After defining the exposed area of the test specimen as $0.5 \times 10^{-4} \mathrm{~m}^{2}$, the remainder was painted with a transparent lacquer. The test was conducted at a potential range of $-0.65 \mathrm{~V}$ to $+1.1 \mathrm{~V}$ vs. SCE (saturated calomel electrode) and at a scanning rate of $1 \times 10^{-3} \mathrm{~V} \mathrm{~s}^{-1}$, using a SCE.

The potentiostatic test was measured in a deaerated $2 \mathrm{M}$ $\mathrm{H}_{2} \mathrm{SO}_{4}$ solution at $333 \mathrm{~K}$ with an respectively applied potential of $-0.2 \mathrm{~V}_{\mathrm{SCE}}$ in the active region and $0.6 \mathrm{~V}_{\mathrm{SCE}}$ in the passive region of the potentiodynamic anodic polarization curves at which a meta-stable pitting can occur. ${ }^{18,19)}$ The current transients were recorded for a duration of $3600 \mathrm{~s}$ and $36000 \mathrm{~s}$.

The specimens used for a surface analysis were polished with $\mathrm{SiC}$ paper to 2000 grit, then polished with a $1 \mu \mathrm{m}$ diamond paste, and washed with acetone. The chemical compositions of each phase were analyzed using a SAM after the potentiostatic polarization test. The Ar sputtering rate was approximately $5 \mathrm{~nm} / \mathrm{min}$. The chemical species in the outermost surface film formed on the alloy were analyzed using an XPS after the potentiostatic test at the respectively applied with $-0.2 \mathrm{~V}_{\mathrm{SCE}}$ in the active region and $0.6 \mathrm{~V}_{\mathrm{SCE}}$ in the passive region in deaerated $2 \mathrm{M} \mathrm{H}_{2} \mathrm{SO}_{4}$ solution for $10 \mathrm{~h}$. The energy source was an $\mathrm{Al}-\mathrm{K} \alpha(1486.6 \mathrm{eV}) \mathrm{X}$-ray, and the acquired spectra were calibrated with a binding energy of C $1 \mathrm{~s}(284.5 \mathrm{eV})$.

Thermodynamic calculations were carried out using thermodynamic calculating software $\left(\right.$ FactSage $\left.^{\mathrm{TM}}\right) .{ }^{20)}$ The
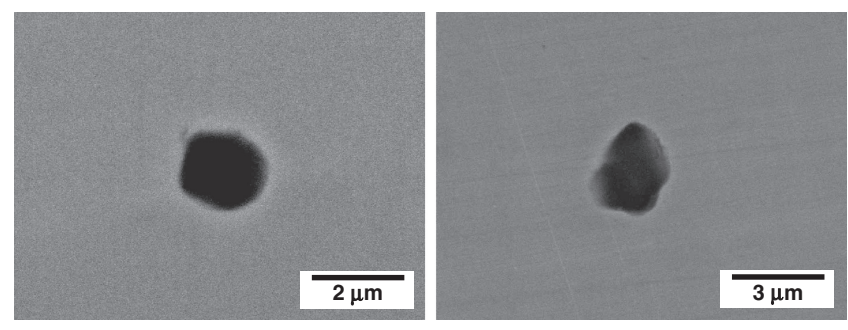

(a)

Type 1

Type 2

\begin{tabular}{|c|c|c|c|c|c|}
\hline \multirow{2}{*}{ Type of inclusion } & \multicolumn{5}{|c|}{ Chemical compositions (mass \%) } \\
\cline { 2 - 6 } & $\mathrm{Cr}$ & $\mathrm{Mn}$ & $\mathrm{Fe}$ & $\mathrm{Al}$ & $\mathrm{O}$ \\
\hline 1 & 42.00 & 16.49 & 26.14 & - & 15.37 \\
\hline 2 & 41.38 & 18.52 & 14.98 & 5.76 & 19.37 \\
\hline
\end{tabular}

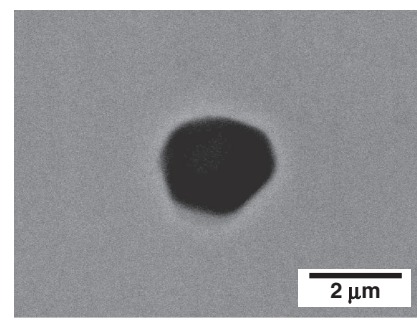

(b)

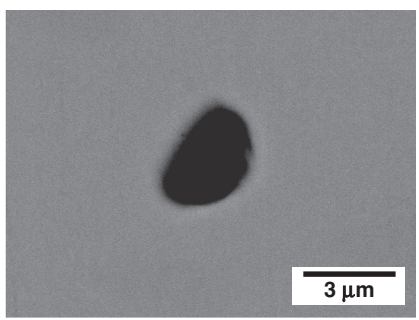

Type 2

\begin{tabular}{|c|c|c|c|c|c|}
\hline \multirow{2}{*}{ Type of inclusion } & \multicolumn{5}{|c|}{ Chemical compositions (mass \%) } \\
\cline { 2 - 6 } & $\mathrm{Cr}$ & $\mathrm{Mn}$ & $\mathrm{Fe}$ & $\mathrm{Al}$ & $\mathrm{O}$ \\
\hline 1 & 39.41 & 17.20 & 26.88 & - & 16.51 \\
\hline 2 & 42.98 & 27.49 & 2.44 & 5.08 & 22.02 \\
\hline
\end{tabular}

Fig. 2 SEM-EDS analysis of inclusions in the alloy: (a) Base alloy and (b) $1.5 \mathrm{Cu}$ alloy.

temperature was set to $333 \mathrm{~K}$. The E-pH (Pourbaix) diagrams were plotted in $\mathrm{Cu}-\mathrm{H}_{2} \mathrm{O}$ and $\mathrm{Cu}-\mathrm{S}-\mathrm{H}_{2} \mathrm{O}$ systems. The activity of $\mathrm{Cu}$ ions was set to $1 \times 10^{-6} \mathrm{~mol} / \mathrm{L}$.

\section{Results and Discussion}

\subsection{Effects of $\mathrm{Cu}$ addition on the distribution and formation behavior of inclusions}

Figure 1 shows the BSE images of the experimental alloys which were solution heat-treated. The dotted circles of the blackish globular particles appeared to be inclusions. No secondary phases such as sigma $(\sigma)$ and chi $(\chi)$ phases were observed in the experimental alloys.

Figure 2 shows the BSE images of the inclusions in the experimental alloys. The chemical compositions of the 

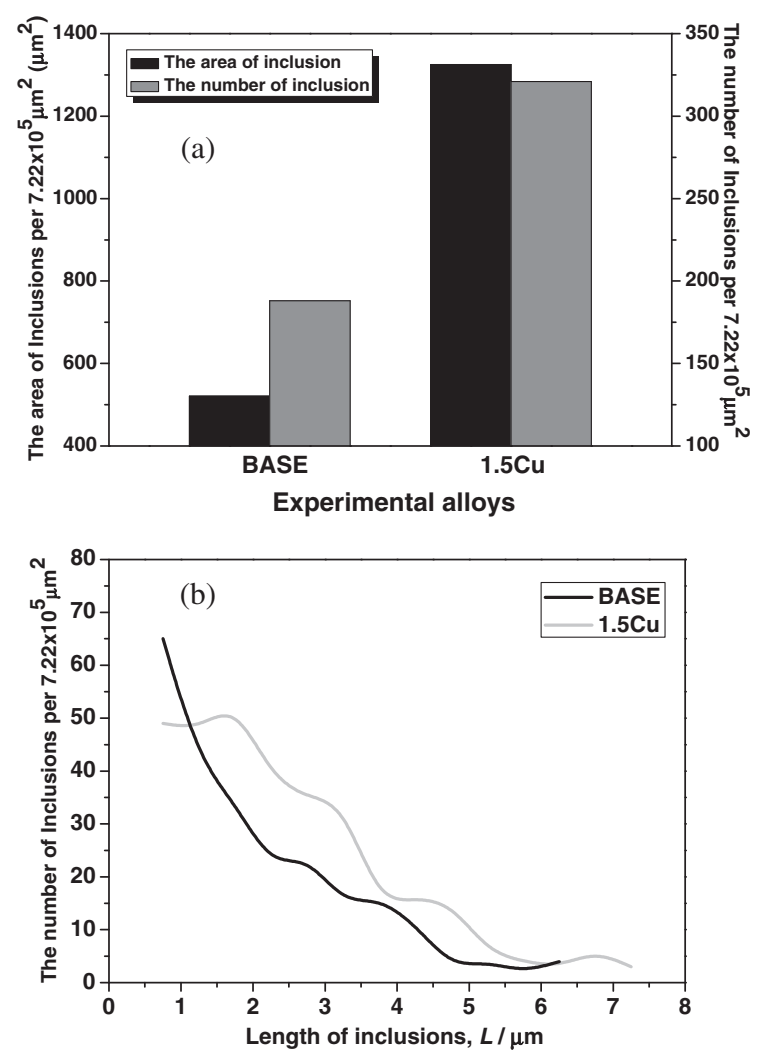

Fig. 3 The number, area and distribution of inclusions per frame area of the alloys: (a) the number and area of inclusions and (b) the distribution of inclusions.

inclusions were analyzed using SEM-EDS. As presented in Fig. 2 (a), the inclusions in the base alloy were composed of the main type of $(\mathrm{Cr}, \mathrm{Mn}, \mathrm{Al})$ oxides and $(\mathrm{Cr}, \mathrm{Mn}, \mathrm{Fe}, \mathrm{Al})$ oxides. Figure 2 (b) shows that the inclusions in the $1.5 \mathrm{Cu}$ alloy were composed of the main type of $(\mathrm{Cr}, \mathrm{Mn}, \mathrm{Al})$ oxides and $(\mathrm{Cr}, \mathrm{Mn}, \mathrm{Fe}, \mathrm{Al})$ oxides The chemical composition of inclusions in the $1.5 \mathrm{Cu}$ alloys was similar to those in the base alloy.

Figure 3 presents the effects of $\mathrm{Cu}$ addition on the number, area, and distribution of inclusions per frame area of the experimental alloys. $\mathrm{Cu}$ addition to the base alloy increased the number of inclusions per frame area (Fig. 3 (a)). The area of inclusions per frame area in the $1.5 \mathrm{Cu}$ alloy was increased by about 2.6 times, compared with that of the base alloy (Fig. 3 (a)). $\mathrm{Cu}$ addition to the base alloy increased the number of coarse inclusions and decreased the number of fine inclusions (Fig. 3 (b)).

In the previous work, The $\mathrm{Cu}$ addition to the duplex stainless steels increased the amount of $\mathrm{Cr}$ oxides and oxysulphides that acted as pitting initiators by increasing the activity of $\mathrm{Cr}$, and resulted in decreasing the pitting corrosion resistance. $^{21)}$

\subsection{Effects of $\mathrm{Cu}$ addition on potentiodynamic and potentiostatic polarization behaviors}

Figure 4 shows the effect of $\mathrm{Cu}$ addition on the potentiodynamic polarization behavior of the experimental alloys in a deaerated $2 \mathrm{M} \mathrm{H}_{2} \mathrm{SO}_{4}$ solution at $333 \mathrm{~K}$ according to ASTM G 5. Table 2 shows the effect of $\mathrm{Cu}$ addition on the corrosion potential $\left(E_{\text {corr }}\right)$, the corrosion current density $\left(I_{\text {corr }}\right)$,

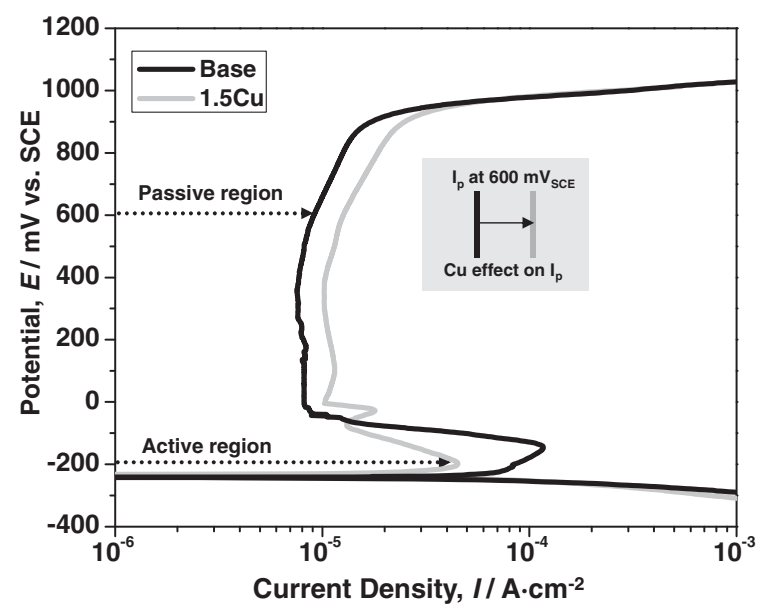

Fig. 4 Potentiodynamic anodic polarization behaviors of the alloys in the deaerated $2 \mathrm{M} \mathrm{H}_{2} \mathrm{SO}_{4}$ solution at $333 \mathrm{~K}$.

Table 2 Electrochemical parameters for the experimental alloys in deaerated $2 \mathrm{M} \mathrm{H}_{2} \mathrm{SO}_{4}$ solutions at $333 \mathrm{~K}$ obtained from the potentiodynamic anodic polarization curves.

\begin{tabular}{cccccc}
\hline Alloy & $\begin{array}{c}E_{\text {corr }} \\
\left(\mathrm{mV}_{\mathrm{SCE}}\right)\end{array}$ & $\begin{array}{c}I_{\text {corr }} \\
\left(\mu \mathrm{A} / \mathrm{cm}^{2}\right)\end{array}$ & $\begin{array}{c}I_{\mathrm{c}} \\
\left(\mu \mathrm{A} / \mathrm{cm}^{2}\right)\end{array}$ & $\begin{array}{c}I_{\mathrm{p}} \text { at } 0.6 \mathrm{~V}_{\mathrm{SCE}} \\
\left(\mu \mathrm{A} / \mathrm{cm}^{2}\right)\end{array}$ & $\begin{array}{c}\text { Corrosion rate } \\
(\mathrm{mpy})\end{array}$ \\
\hline Base & -241 & 61.4 & 121.5 & 10.2 & 24.8 \\
\hline $1.5 \mathrm{Cu}$ & -232 & 21.8 & 45.3 & 12.7 & 8.8 \\
\hline
\end{tabular}

the critical current density $\left(I_{\mathrm{c}}\right)$ and the passivation current density $\left(I_{\mathrm{p}}\right)$ obtained from Fig. 4 . Based upon a decrease of the $I_{\mathrm{c}}$ and $I_{\text {corr }}$ in active region, the active corrosion resistance of the $1.5 \mathrm{Cu}$ alloy in a deaerated $2 \mathrm{M} \mathrm{H}_{2} \mathrm{SO}_{4}$ solution at $60^{\circ} \mathrm{C}$ was higher than that of the base alloy. In particular, the active corrosion resistance in active region of the $1.5 \mathrm{Cu}$ alloy was much higher than that of the base alloy because $I_{\mathrm{c}}$ $\left(0.0453 \mathrm{~mA} / \mathrm{cm}^{2}\right)$ of $1.5 \mathrm{Cu}$ alloy is much smaller than that $\left(0.1215 \mathrm{~mA} / \mathrm{cm}^{2}\right)$ of the base alloy. The addition of $\mathrm{Cu}$ lowers the $I_{\mathrm{c}}$ and facilitates the formation of passivation. This result can be related to the tendency of $\mathrm{Cu}$ to reduce the overpotential of the cathodic reaction, thus promoting activepassive transition. ${ }^{22)}$ An additional factor is the affinity of $\mathrm{Cu}$ for oxygen, which could facilitate adsorption of oxygen and enhance the passivation process. ${ }^{8)}$ Hence, it is concluded that the $\mathrm{Cu}$ addition has a positive effect on the active corrosion resistance of the alloys in the sulfuric acid solution. On the other hand, in the passive region, $I_{\mathrm{p}}\left(12.7 \mu \mathrm{A} / \mathrm{cm}^{2}\right)$ of $1.5 \mathrm{Cu}$ alloy is larger than that $\left(10.2 \mu \mathrm{A} / \mathrm{cm}^{2}\right)$ of the base alloy. Based upon the increase of the $I_{\mathrm{p}}$, the addition of $\mathrm{Cu}$ to the base alloy has a negative effect on the passivation behavior.

Figure 5 presents the effect of the $\mathrm{Cu}$ addition on the potentiostatic test for the experimental alloys at the applied potential of $-0.2 \mathrm{~V}_{\mathrm{SCE}}$ in the active region of the potentiodynamic polarization curves of Fig. 4 in the deaerated $2 \mathrm{M}$ $\mathrm{H}_{2} \mathrm{SO}_{4}$ at $333 \mathrm{~K}$. The potentiostatic test was performed in order to observe the current transients at a primary passivation potential $\left(E_{\mathrm{pp}}\right)$ that corresponds to the critical current density at the potentiodynamic anodic polarization curves. The addition of $\mathrm{Cu}$ to the base alloy decreases the critical current density. 


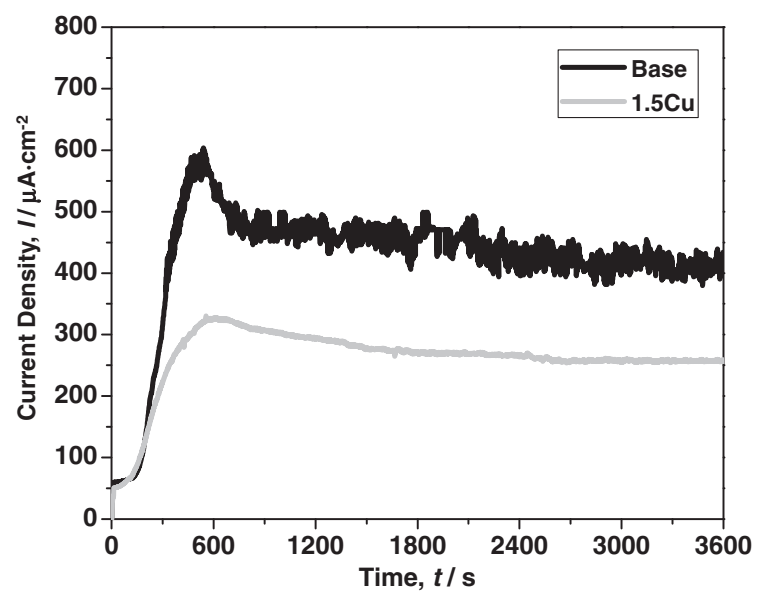

Fig. 5 The potentiostatic polarization tests at an applied potential of $-0.2 \mathrm{~V}_{\mathrm{SCE}}$ (active region) of the alloys in deaerated $2 \mathrm{M} \mathrm{H}_{2} \mathrm{SO}_{4}$ solution at $333 \mathrm{~K}$.

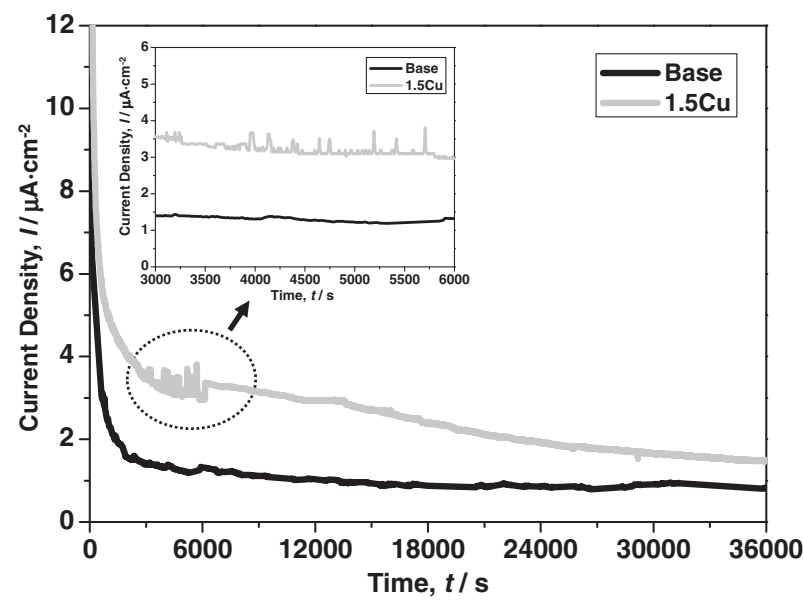

Fig. 6 The potentiostatic polarization tests at an applied potential of $0.6 \mathrm{~V}_{\mathrm{SCE}}$ (passive region) of the alloys in deaerated $2 \mathrm{M} \mathrm{H}_{2} \mathrm{SO}_{4}$ solution at $333 \mathrm{~K}$.

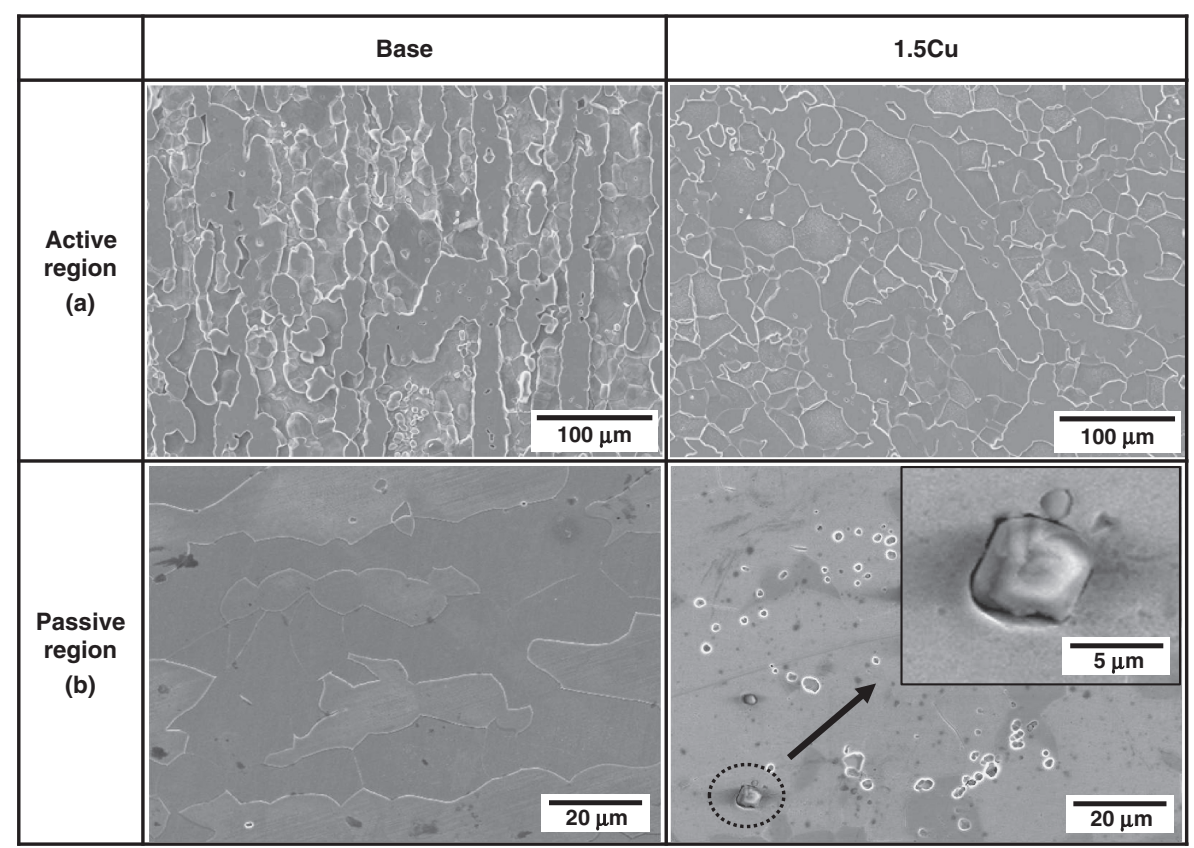

Fig. 7 SEM image of the inclusions in the alloys after the potentiostatic test in deaerated $2 \mathrm{M} \mathrm{H}_{2} \mathrm{SO}_{4}$ solution at $333 \mathrm{~K}$ : (a) at an applied potential of $-0.2 \mathrm{~V}_{\mathrm{SCE}}$ and (b) at an applied potential of $0.6 \mathrm{~V}_{\mathrm{SCE}}$.

Figure 6 presents the effect of the $\mathrm{Cu}$ addition on the potentiostatic test for the experimental alloys at the applied potential of $0.6 \mathrm{~V}_{\mathrm{SCE}}$ in the passive region of the potentiodynamic polarization curves of Fig. 4 in the deaerated $2 \mathrm{M}$ $\mathrm{H}_{2} \mathrm{SO}_{4}$ at $333 \mathrm{~K}$. The $I_{\mathrm{p}}$ of the $1.5 \mathrm{Cu}$ alloy is higher than that of the base alloy. Furthermore, numerous current transients that indicate the metastable pitting and repassivation at the inclusions occuring in test period from $3000 \mathrm{~s}$ to $6000 \mathrm{~s}$ in the potentiostatic curve of the $1.5 \mathrm{Cu}$ alloy, compared with that of the base alloy.

Figure 7 presents the SEM image of the surface morphologies after potentiostatic tests at the applied potential of -0.2 and $0.6 \mathrm{~V}_{\mathrm{SCE}}$ of the experimental alloys in deaerated $2 \mathrm{M}$ $\mathrm{H}_{2} \mathrm{SO}_{4}$ solutions at $333 \mathrm{~K}$. In the active region, the base alloy without $\mathrm{Cu}$ is more corroded than $1.5 \mathrm{Cu}$ alloy (Fig. 7 (a)). As presented in Fig. 7 (b), the $1.5 \mathrm{Cu}$ alloy was corroded more than that of the base alloy. Considering the $I_{\mathrm{p}}$ and surface morphology after the potentiostatic test, the passivity of the $1.5 \mathrm{Cu}$ alloy was inferior to the base alloy. The deterioration of the general corrosion resistance in passive region as a result of an increase in the $\mathrm{Cu}$ addition seems to be associated with the increase in the area fraction of the inclusions per frame area in the alloy. ${ }^{21,23-25)}$ That is, as the interface areas between the inclusion and the matrix in the alloy increased with an increase in the $\mathrm{Cu}$ addition, the preferential sites for the initiation of corrosion in the alloy were increased.

In summary, based upon a decrease of the $I_{\text {corr }}$ and $I_{\mathrm{c}}$, the addition of $\mathrm{Cu}$ to the base alloy considerably enhanced the general corrosion resistance in the active region. In the passive region, based upon the increase of the $I_{\mathrm{p}}$, the addition of $\mathrm{Cu}$ to the base alloy deteriorated the corrosion resistance. 


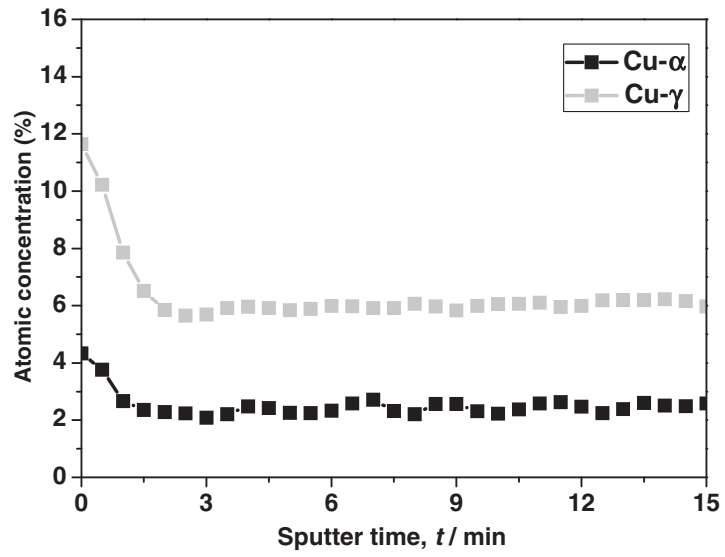

Table 3 The binding energies of some chemical species for the XPS analysis.

\begin{tabular}{cccc}
\hline Species & $\begin{array}{c}\text { Binding energies } \\
(\mathrm{eV})\end{array}$ & Species & $\begin{array}{c}\text { Binding energies } \\
(\mathrm{eV})\end{array}$ \\
\hline $\mathrm{Fe}(\mathrm{M})_{2 \mathrm{p} 3 / 2}$ & 706.7 & $\mathrm{Cu}(\mathrm{M})_{2 \mathrm{p} 3 / 2}$ & 932.5 \\
$\mathrm{FeO}_{2 \mathrm{p} 3 / 2}$ & 709.4 & $\mathrm{CuO}_{2 \mathrm{p} 3 / 2}$ & 933.6 \\
$\mathrm{Fe}_{2} \mathrm{O}_{32 \mathrm{p} 3 / 2}$ & 710.9 & $\mathrm{Cu}(\mathrm{OH})_{22 \mathrm{p} 3 / 2}$ & 934.4 \\
$\mathrm{Fe}_{2} \mathrm{O}_{32 \mathrm{p} 3 / 2}$ & 715.4 & $\mathrm{Cu}(\mathrm{OH})_{22} 2 \mathrm{p} 3 / 2$ & 935.1 \\
& & & \\
$\mathrm{Cr}_{2}(\mathrm{M})_{2 \mathrm{p} 3 / 2}$ & 573.8 & $\mathrm{FeSO}_{42} 2 \mathrm{p} 3 / 2$ & 168.3 \\
$\mathrm{Cr}_{2} \mathrm{O}_{32} 2 \mathrm{p} 3 / 2$ & 576.4 & $\mathrm{CuSO}_{42} 2 \mathrm{p} 3 / 2$ & 169.1 \\
$\mathrm{Cr}_{2}(\mathrm{OH})_{32 \mathrm{p} 3 / 2}$ & 577.3 & $\mathrm{CuSO}_{4} \cdot 5 \mathrm{H}_{2} \mathrm{O}_{2 \mathrm{p} 3 / 2}$ & 169.5 \\
$\mathrm{CrO}_{32 \mathrm{p} 3 / 2}$ & 578.1 & & \\
\hline
\end{tabular}

Fig. 8 The $\mathrm{Cu}$ of Auger depth profile in the $1.5 \mathrm{Cu}$ alloy after the potentiostatic polarization test at an applied potential of $-0.2 \mathrm{~V}_{\mathrm{SCE}}$ in the deaerated $2 \mathrm{M} \mathrm{H}_{2} \mathrm{SO}_{4}$ solution at $333 \mathrm{~K}$.

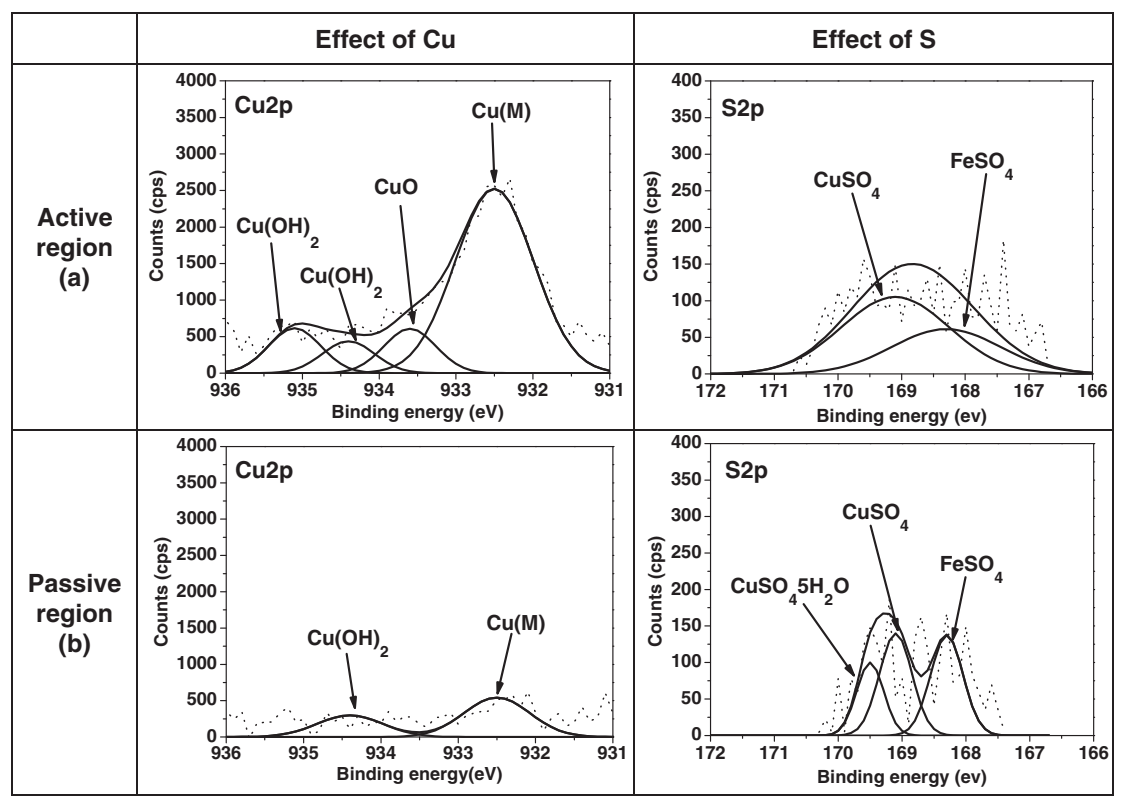

Fig. 9 Deconvolution of $\mathrm{Cu}$ and $\mathrm{S}$ related chemical species by the XPS in the outer surface film formed on the $1.5 \mathrm{Cu}$ alloy after the potentiostatic test for $10 \mathrm{~h}$ in deaerated $2 \mathrm{M} \mathrm{H}_{2} \mathrm{SO}_{4}$ solutions at $333 \mathrm{~K}$ : (a) at an applied potential of $-0.2 \mathrm{~V}_{\mathrm{SCE}}$ (active region) and (b) at an applied potential of $0.6 \mathrm{~V}_{\mathrm{SCE}}$ (passive region).

\subsection{Effects of $\mathrm{Cu}$ addition on the passivation behaviors}

Figure 8 shows Auger depth profile of the $\alpha$-phases and $\gamma$ phases in the $1.5 \mathrm{Cu}$ alloy after the potentiostatic polarization test at an applied potential of $-0.2 \mathrm{~V}_{\mathrm{SCE}}$ (active region) in the deaerated $2 \mathrm{M} \mathrm{H}_{2} \mathrm{SO}_{4}$ solution at $333 \mathrm{~K}$. As shown in the Fig. 8 the $\mathrm{Cu}$ which act as $\gamma$-stabilizers, are enriched in the $\gamma$-phase and are diluted in the $\alpha$-phase, while the atomic concentration of the $\mathrm{Cu}$ in the outermost surface film of both the $\alpha$-phases and $\gamma$-phases film increased significantly compared with that of the substrate. This indicates that the novel metals such as $\mathrm{Cu}$ can be enriched on the alloy surface due to the selective dissolution of the active metals such as Fe, $\mathrm{Cr}$, and $\mathrm{Ni}$ in the alloy. Consequently, $\mathrm{Cu}$ can contribute to the general corrosion resistance. In particular, the $\mathrm{Cu}$ on the outermost surface film of the $\gamma$-phase was enriched by approximately 11.8 at\%, which is much larger than that of the substrate and that of the $\alpha$-phase was enriched by approximately 4.2 at\%, which is also larger than that of the substrate.
Figure 9 shows that the deconvolution of $\mathrm{Cu}$ and $\mathrm{S}$ related chemical species by the XPS in the outer surface film formed on the $1.5 \mathrm{Cu}$ alloy after the potentiostatic test at the applied potential of $-0.2 \mathrm{~V}_{\mathrm{SCE}}$ (active region) and $0.6 \mathrm{~V}_{\mathrm{SCE}}$ (passive region) for $10 \mathrm{~h}$ in deaerated $2 \mathrm{M} \mathrm{H}_{2} \mathrm{SO}_{4}$ solutions at $333 \mathrm{~K}$. In the active region of $-0.2 \mathrm{~V}_{\mathrm{SCE}}$, the chemical species related to $\mathrm{Cu}$ and $\mathrm{S}$ in the outermost surface film were analyzed using XPS (Fig. 9 (a)). The binding energy of each chemical element used for the XPS analysis is given in Table 3. For $1.5 \mathrm{Cu}$ alloy, existed as $\mathrm{Cu}(\mathrm{M})$, cupric oxide $(\mathrm{CuO})$ and copper hydroxide $\left(\mathrm{Cu}[\mathrm{OH}]_{2}\right)$; $\mathrm{S}$ existed as copper sulfate $\left(\mathrm{CuSO}_{4}\right)$ and iron sulfate $\left(\mathrm{FeSO}_{4}\right)$ (Fig. 9 (a)). Based on the results of the XPS analysis, the contribution of the $\mathrm{Cu}$ addition to the enhancement of active corrosion resistance can be explained as the followings. The novel metals such as $\mathrm{Cu}$ can be enriched on the alloy surface due to the selective dissolution of the active metals such as $\mathrm{Fe}, \mathrm{Cr}$, and $\mathrm{Ni}$ in the alloy. Consequently, $\mathrm{Cu}$ can contribute to the corrosion 
(a) $\mathrm{pH}$ of the $2 \mathrm{M} \mathrm{H}_{2} \mathrm{SO}_{4}$

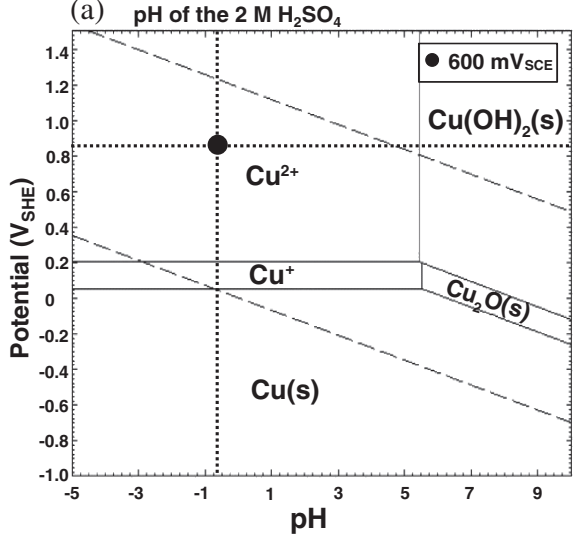

(b)

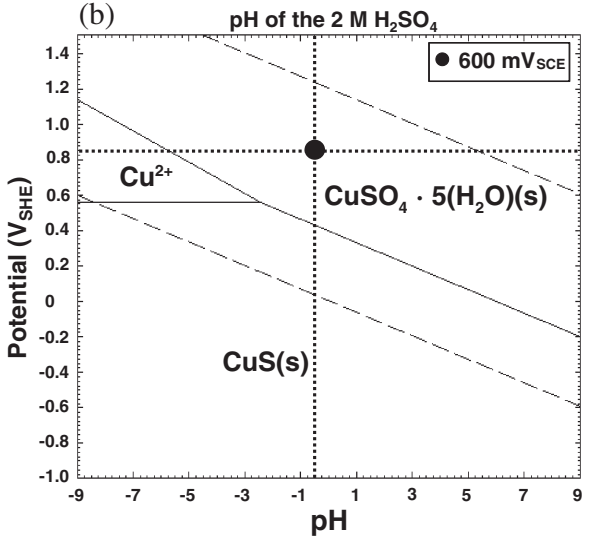

Fig. 10 E-pH diagram for the (a) $\mathrm{Cu}-\mathrm{H}_{2} \mathrm{O}$ system at $333 \mathrm{~K}$ and (b) $\mathrm{Cu}-\mathrm{S}-\mathrm{H}_{2} \mathrm{O}$ system at $333 \mathrm{~K}$.

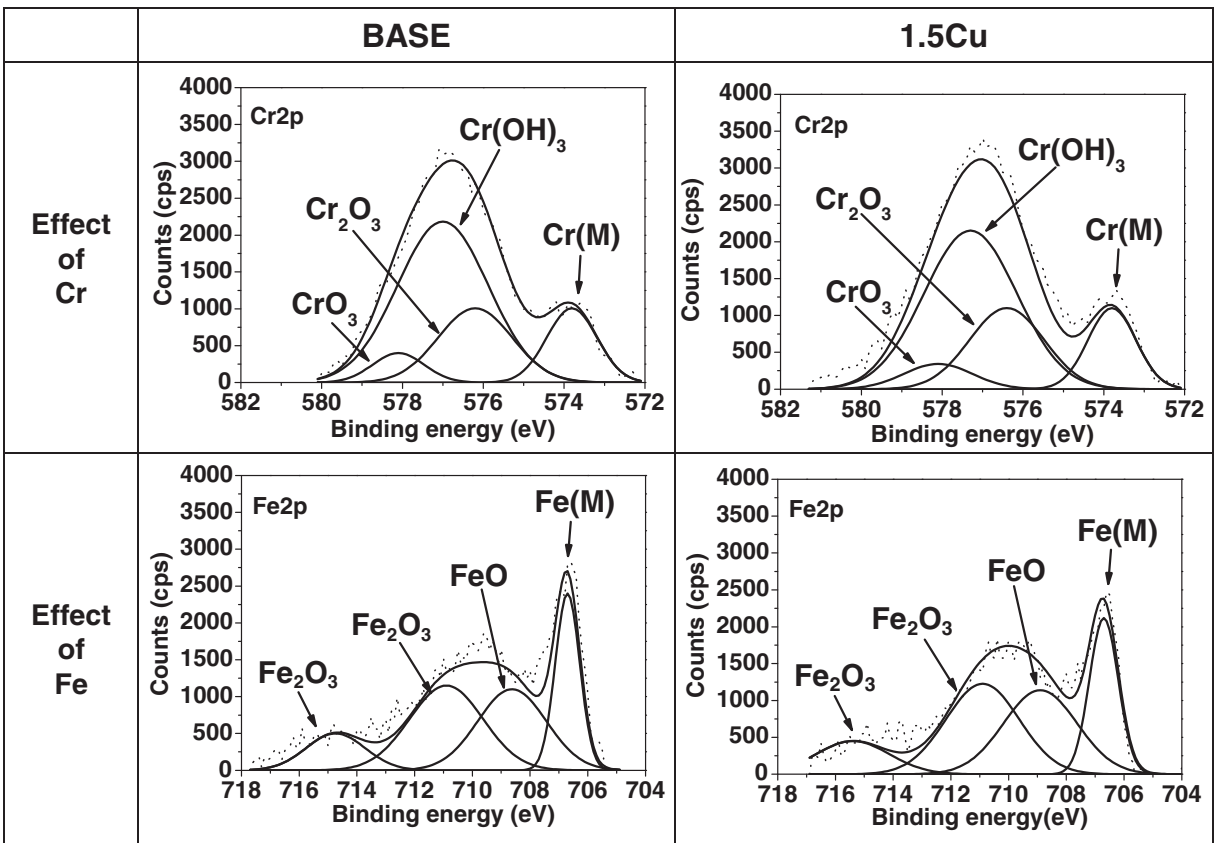

Fig. 11 Deconvolution of $\mathrm{Cr}$ and Fe related chemical species by the XPS in the outer surface film formed on the alloys after the potentiostatic test for $10 \mathrm{~h}$ at an applied potential of $0.6 \mathrm{~V}_{\mathrm{SCE}}$ in deaerated $2 \mathrm{M} \mathrm{H}_{2} \mathrm{SO}_{4}$ solutions at $333 \mathrm{~K}$.

resistance. In addition, $\mathrm{Cu}$ addition to the base alloy forms the insoluble $\mathrm{CuO}$ in the relative oxide state and $\mathrm{Cu}(\mathrm{OH})_{2}$, which greatly enhances the active corrosion resistance, compare with that of base alloy.

In the passive region of $0.6 \mathrm{~V}_{\mathrm{SCE}}$, the chemical species related to $\mathrm{Cu}$ and $\mathrm{S}$ in the outermost surface film were analyzed using XPS (Fig. 9 (b)). As $\mathrm{Cu}$ added, the $\mathrm{Cu}(\mathrm{M})$ is not existed and it is dissolved from the passive film due to its oxidization from $\mathrm{Cu}$ to $\mathrm{Cu}^{2+}$ in the potentiostatic polarization test region. The binding energy of each chemical element used for the XPS analysis is given in Table 3. For $1.5 \mathrm{Cu}$ alloy, $\mathrm{S}$ existed as hydrous copper sulfate $\left(\mathrm{CuSO}_{4} \cdot 5 \mathrm{H}_{2} \mathrm{O}\right)$, copper sulfate $\left(\mathrm{CuSO}_{4}\right)$ and iron sulfate $\left(\mathrm{FeSO}_{4}\right)$ (Fig. 9 (b)).

Figure 10 shows the E-pH (Pourbaix) diagram of the $\mathrm{Cu}$ $\mathrm{H}_{2} \mathrm{O}$ and $\mathrm{Cu}-\mathrm{S}-\mathrm{H}_{2} \mathrm{O}$ systems at $333 \mathrm{~K}$ calculated by FactSage software ${ }^{20)}$ respectively. As presented in Fig. 10 (a), the E$\mathrm{pH}$ diagram for the $\mathrm{Cu}-\mathrm{H}_{2} \mathrm{O}$ at $333 \mathrm{~K}$ and the potential values are given with respect to SHE (standard hydrogen electrode) at $333 \mathrm{~K}$ supporting the dissolution of $\mathrm{Cu}$ in the passive region. $\mathrm{Cu}$ did not exist as the noble metal state because it was oxidized as $\mathrm{Cu}^{2+}$ in the potentiostatic polarization test region $\left(0.6 \mathrm{~V}_{\mathrm{SCE}}=0.841 \mathrm{~V}_{\mathrm{SHE}}\right)$. However, as presented in Fig. 10 (b), the $\mathrm{Cu}$ was oxidized as the $\mathrm{CuSO}_{4}$ in the sulfuric acid solution as following reaction.

$$
\mathrm{Cu}+\mathrm{SO}_{4}{ }^{2-}+5 \mathrm{H}_{2} \mathrm{O}=\mathrm{CuSO}_{4} \cdot 5 \mathrm{H}_{2} \mathrm{O}+2 \mathrm{e}^{-}
$$

In the passive region of $0.6 \mathrm{~V}_{\mathrm{SCE}}$, the chemical species related to $\mathrm{Cr}$ and $\mathrm{Fe}$ in the outermost surface film were analyzed using XPS. The results are presented in Fig. 11. The binding energy of each chemical element used for the XPS analysis is given in Table 3. For the experimental alloys, $\mathrm{Fe}$ existed as $\mathrm{Fe}(\mathrm{M})$, iron(III) oxide $\left(\mathrm{Fe}_{2} \mathrm{O}_{3}\right)$ and iron(II) oxide (FeO); $\mathrm{Cr}$ existed as $\mathrm{Cr}(\mathrm{M})$, chromium(III) oxide $\left(\mathrm{Cr}_{2} \mathrm{O}_{3}\right)$, chromium trioxide $\left(\mathrm{CrO}_{3}\right)$ and chromium hydroxide $\left(\mathrm{Cr}(\mathrm{OH})_{3}\right)$. Table 4 shows the elemental ratios of $\mathrm{Cr}$ to $\mathrm{Fe}$ calculated from the XPS analysis of Fig. 11 for the experimental alloys after the potentiostatic test of the experimental alloy at the applied potential of $0.6 \mathrm{~V}_{\mathrm{SCE}}$ in 
Table 4 Elemental ratios of $\mathrm{Cr}$ to $\mathrm{Fe}$ calculated from the XPS survey spectrum for the experimental alloys after the potentiostatic test for $10 \mathrm{~h}$ at an applied potential of $0.6 \mathrm{~V}_{\mathrm{SCE}}$ in deaerated $2 \mathrm{M} \mathrm{H}_{2} \mathrm{SO}_{4}$ solutions at $333 \mathrm{~K}$ using peak area and atomic sensitivity factors.

\begin{tabular}{|c|c|c|c|c|c|c|c|}
\hline \multirow{3}{*}{ Alloy } & \multicolumn{4}{|c|}{ Peak area } & \multirow{2}{*}{\multicolumn{2}{|c|}{$\begin{array}{l}\text { Elemental } \\
\text { atomic \% }\end{array}$}} & \multirow{3}{*}{$\begin{array}{c}\text { Atomic } \\
\text { ratio of } \\
\mathrm{Cr} / \mathrm{Fe}\end{array}$} \\
\hline & \multicolumn{2}{|c|}{$\mathrm{Cr}$} & \multicolumn{2}{|c|}{$\mathrm{Fe}$} & & & \\
\hline & $\begin{array}{l}\text { Total } \\
\text { area }\end{array}$ & $\begin{array}{c}\text { Area } \\
/ \mathrm{ASF} \\
(\mathrm{Cr} ; 1.5)\end{array}$ & $\begin{array}{l}\text { Total } \\
\text { area }\end{array}$ & $\begin{array}{l}\text { Area } \\
\text { /ASF } \\
(\mathrm{Fe} ; 2)\end{array}$ & $\mathrm{Cr}$ & $\mathrm{Fe}$ & \\
\hline Base & 10820 & 7213 & 10531 & 5266 & 57.8 & 42.2 & 1.37 \\
\hline $1.5 \mathrm{Cu}$ & 11100 & 7400 & 11905 & 5953 & 55.4 & 44.6 & 1.24 \\
\hline
\end{tabular}

the deaerated $2 \mathrm{M} \mathrm{H}_{2} \mathrm{SO}_{4}$ solutions at $333 \mathrm{~K}$. The addition of $\mathrm{Cu}$ to the base alloy decreased the elemental ratio of $\mathrm{Cr}$ to $\mathrm{Fe}$ of the passivated alloys.

It is necessary to verify the mechanism of the effects of $\mathrm{Cu}$ addition on the general corrosion behavior in the active and passive region separately. In the active region, based on the results of the XPS analysis after the potentiostatic test at an applied potential of $-0.2 \mathrm{~V}_{\mathrm{SCE}}$ for $10 \mathrm{~h}$ of the $1.5 \mathrm{Cu}$ alloy in the deaerated $2 \mathrm{M} \mathrm{H}_{2} \mathrm{SO}_{4}$ solutions at $333 \mathrm{~K}$, the contribution of the $\mathrm{Cu}$ addition to the enhancement of corrosion resistance can be explained as the followings. The novel metals such as $\mathrm{Cu}$ can be enriched on the alloy surface due to the selective dissolution of the active metals such as $\mathrm{Fe}, \mathrm{Cr}$, and $\mathrm{Ni}$ in the alloy. Consequently, $\mathrm{Cu}$ can contribute to the general corrosion resistance. For the $\mathrm{Cu}$ added alloy, existed as $\mathrm{Cu}$ (M), cupric oxide $(\mathrm{CuO})$ and copper hydroxide $\left(\mathrm{Cu}[\mathrm{OH}]_{2}\right) ; \mathrm{S}$ existed as copper sulfate $\left(\mathrm{CuSO}_{4}\right)$ and iron sulfate $\left(\mathrm{FeSO}_{4}\right)$. The layer of oxidized products is composed mainly of $\mathrm{Cu}$ (M), $\mathrm{CuO}, \mathrm{Cu}[\mathrm{OH}]_{2}, \mathrm{CuSO}_{4}$ and $\mathrm{FeSO}_{4}$ (Fig. 9 (a)). The deposition of these elements and compounds reduces the corrosion rate of $\mathrm{Cu}$ added alloy in deaerated $2 \mathrm{M} \mathrm{H}_{2} \mathrm{SO}_{4}$ solutions at $333 \mathrm{~K}$.

In the passive region, based on the results of XPS surface analysis after the potentiostatic test of the experimental alloy at the applied potential of $0.6 \mathrm{~V}_{\mathrm{SCE}}$ in the deaerated $2 \mathrm{M}$ $\mathrm{H}_{2} \mathrm{SO}_{4}$ solutions at $333 \mathrm{~K}$, the reasons that the corrosion resistance with the addition of $\mathrm{Cu}$ decreased are as follows: the $\mathrm{Cr}$ metal, oxides and hydro-oxide such as metallic $\mathrm{Cr}$ (M), $\mathrm{Cr}_{2} \mathrm{O}_{3}, \mathrm{CrO}_{3}$, and $\mathrm{Cr}[\mathrm{OH}]_{3}$ to enhance the corrosion resistance at the passive region decreased (Fig. 11). The decrease of the $\mathrm{Cr}(\mathrm{M})$, oxide and hydro-oxide as the result of the $\mathrm{Cu}$ addition seems to be associated with the inclusions in the alloy. That is, the addition of $\mathrm{Cu}$ enhanced the driving force of the formation reaction of $\mathrm{Cr}$ containing oxide phases during melting and solidification processes, thereby increasing the formation of $\mathrm{Cr}$ enriched oxide inclusions. As the interface areas between the $\mathrm{Cr}$ enriched oxide inclusion and the matrix in the alloy increased with an increase in the $\mathrm{Cu}$ addition, the preferential sites for the initiation of corrosion in the alloy were increased. Hence, it is clarified that $\mathrm{Cu}$ addition to the base alloy degraded the passivity of the alloy due to increasing the formation of $\mathrm{Cr}$ enriched oxide inclusions acting as the defect in the passive film, resulting in deteriorating the corrosion resistance.

\section{Conclusions}

(1) In the active region of $-0.2 \mathrm{~V}_{\mathrm{SCE}}$, the $\mathrm{Cu}$ addition to the base alloy has a positive effect on the general corrosion resistance of the alloys in the sulfuric acid solution. Based on the results of the XPS analysis, the novel metallic $\mathrm{Cu}$ enriched on the alloy surface enhances the active corrosion resistance. In addition, the deposition of $\mathrm{CuO}, \mathrm{Cu}(\mathrm{OH})_{2}, \mathrm{CuSO}_{4}$ and $\mathrm{FeSO}_{4}$ reduces the general corrosion rate of the $\mathrm{Cu}$ added alloy in the deaerated $2 \mathrm{M} \mathrm{H}_{2} \mathrm{SO}_{4}$ solutions at $333 \mathrm{~K}$.

(2) In the passive region of $0.6 \mathrm{~V}_{\mathrm{SCE}}$, the addition of $\mathrm{Cu}$ to the base alloy has a negative effect on the passivation behavior. The $\mathrm{Cu}$ addition to the alloy degraded the passivity due to the increase of the formation of the $\mathrm{Cr}$ enriched oxide inclusions acting as the defect in the passive film, resulting in the deterioration of the corrosion resistance.

\section{REFERENCES}

1) J. Olson and S. Nordin: Duplex Stainless Steel. Proc., The Hegue, (1986) p. 219.

2) E. Perteneder, J. Tosch, P. Reiterer and G. Rabensteiner: Duplex Stainless Steel. Symp. Proc., The Hegue, (1986) p. 48.

3) J.-O. Nilsson: Mater. Sci. Technol. 8 (1992) 685.

4) M. Seo, G. Hultquist, C. Leygraf and N. Sato: Corros. Sci. 26 (1986) 949.

5) Y. Jiangnan, W. Lichang and S. Wenhao: Corros. Sci. 33 (1992) 851.

6) G. Hultquist, M. Seo, T. Leitner, C. Leygraf and N. Sato: Corros. Sci. 27 (1987) 937

7) T. Ujiro, S. Satoh, R. W. Staehle and W. H. Smyrl: Corros. Sci. 43 (2001) 2185.

8) H. T. Lin, W. T. Tsai, J. T. Lee and C. S. Huang: Corros. Sci. 33 (1992) 691.

9) J. Banas and A. Mazurkiewicz: Mater. Sci. Eng. A 277 (2000) 183.

10) A. Pardo, M. C. Merino, M. Carboneras, F. Viejo, R. Arrabal and J. Munoz: Corros. Sci. 48 (2006) 1075.

11) B. E. Wilde and N. D. Greene, Jr.: Corrosion 25 (1969) 300.

12) D. Itzhak and P. Peled: Corros. Sci. 26 (1986) 49.

13) M. Seo, G. Hultquist, C. Leygraf and N. Sato: Corros. Sci. 26 (1986) 949.

14) E. A. Lizovs: Corrosion 22 (1966) 279.

15) B. Postrach, I. Garz and H. H. Strehblow: Mater. Corros. 45 (1994) 508.

16) E. E. Oguzie, J. Li, Y. Liu, D. Chen, Y. Li, K. Yang and F. Wang: Electrochim. Acta 55 (2010) 5028.

17) ANNUAL BOOK of ASTM STANDARDS, ASTM G 5.

18) G. T. Burstein, P. C. Pistorius and S. P. Mattin: Corros. Sci. 35 (1993) 57.

19) P. C. Pistorius and G. T. Burstein: Corros. Sci. 33 (1992) 1885.

20) C. W. Bale, E. Bélisle, P. Chartrand, S. A. Decterov, G. Eriksson, K. Hack, I. H. Jung, Y. B. Kang, J. Melançon, A. D. Pelton, C. Robelin and S. Petersen: Calphad 33 (2009) 295.

21) S. H. Jeon, S. T. Kim, I. S. Lee, J. H. Park, K. T. Kim, J. S. Kim and Y. S. Park: Corros. Sci. 53 (2011) 1408.

22) J. Banas and A. Mazurkiewicz: Mater. Sci. Eng. A 277 (2000) 183

23) J. Stewart and D. E. Williams: Corros. Sci. 33 (1992) 457.

24) S. T. Kim, S. H. Jeon, I. S. Lee and Y. S. Park: Corros. Sci. 52 (2010) 1897.

25) S. H. Jeon, S. T. Kim, I. S. Lee and Y. S. Park: Corros. Sci. 52 (2010) 3537. 